\title{
Strategic plans for ALA and ACRL:
}

\section{A comparison}

\section{How ACRL's Goals and Strategic Management Directions relate to ALA's Priority and Organizational Areas.}

D uring the same period when ACRL was working on its Strategic Plan, ALA was involved in a similar process. This has also been the case with other units of ALA - divisions, offices, and administrative units. A big question in the minds of all members and staff has been, "How will the plans of the units and the whole fit together?" At several sessions during ALA Annual Conferences and Midwinter Meetings, groups of members have discussed the potential problems in the overlapping planning processes, and have tried to avoid serious inconsistencies among all the plans.

As an exercise, a comparison was drawn between ALA's Strategic Long-Range Plan, which contains six Priority Areas and three Organiza- tional Support Goals, and ACRL's Strategic Plan, with its four Goals and seven Strategic Management Directions.

The following chart shows this comparison. On the left are the ALA Priority Areas. On the right, those parts of the ACRL Strategic Plan that relate to the ALA Plan are identified. The numbering system in the ACRL column gives a goal number (Roman numeral), a letter identifying the sub-goal, and a number for the objective involved. ACRL's Strategic Plan will soon be available in three formats: the full report is being deposited in ERIC, a brief form will be published next month in $C \downarrow R L$ News, and a brochure on the Plan will appear by the Midwinter Meeting.

\section{Priority Area A: Access to Information}

1. All individuals have equal access to libraries and information services.

2. Government information is widely and easily available.

3. Library collections are developed and maintained to meet the information needs of users.

4. Access to information is facilitated by bibliographic organization.

5. Library use is high.
II.E. To strengthen libraries in institutions serving minorities.

IV.C.3. Publish Choice and Books for College Libraries on a regular basis. 


\section{Priority Area B: Legislation/Funding}

1. Libraries have adequate funding from public sources (local, state, federal).

2. ALA members are well informed about opportunities for raising funds from private sources.

3 . Reliable and timely statistics and information about all sources of library funding are available.

4 . Congress consistently approves legislation favorable to libraries.

5. Local governing authorities and state legislatures consistently approve ordinances and legislation favorable to libraries.
III.B.3. Provide assistance for librarians seeking additional support for their libraries.

III.B.3b. Cooperate with LAMA or another group in presenting a fund-raising workshop.

II.A.4. Promote the identification, collection, and dissemination of academic library statistics.

II.B.2. Strengthen members' efforts to affect and influence government and private sector activities, including legislation, funding, and quality higher education.

\section{Priority Area C: Intellectual Freedom}

1. First Amendment rights are secure.

2. Persons whose First Amendment rights are challenged have adequate support.

\section{Priority Area D: Public Awareness}

1. ALA provides information about libraries to all.

2. Librarians are recognized as proactive professionals responsible for ensuring the free flow of information and ideas to present and future generations of library users.

3. Libraries are recognized as proactive agencies essential to the cultural, educational and economic life of society.
II.A.2. Increase dissemination of ACRL standards and guidelines throughout the higher education community.

II.B. Publicize availability of Advisory Services.

IIII.A. To enhance awareness of the role of academic and research libraries among non-library professionals and organizations (accrediting bodies, higher education associations, scholarly and professional societies, etc.) and to develop effective working relationships with them.

\section{Priority Area E: Personnel Resources}

1. Library and information science education meets the changing library and information needs of society.

2. Master's level programs are effectively accredited.

3. Librarians are paid attractive salaries.

4. Librarians have a variety of opportunities for professional development and continuing education.

5. Workshops and conferences conducted by ALA are available to librarians, trustees, and others interested in libraries.

6. Job information, placement, and career services are readily available to librarians.
III.D. To help shape library education programs in accord with the needs of academic and research librarianship.

I. To contribute to the total professional development of academic and research librarians.

I.C. To provide career counseling and placement information regarding academic and research librarianship. 
7. Effective library personnel policies are established and used.

8. Librarianship recruits a racially and ethnically diverse group of high caliber persons.

9. Librarians uphold the ALA Code of Ethics.

10. Librarians are proactive professionals who ensure the free flow of information and ideas.
III.C. 3. Promote the adoption of personnel policies that enhance the status, professional development and working conditions of academic librarians.

III.C.2. Support the recruitment of members of underrepresented groups to academic librarianship.

\section{Priority Area F: Library Services, Development, and Technology}

1. Guidelines, standards, and codes are formulated and promoted to facilitate effective library service.

2. Professional resources in a variety of formats are produced by ALA.

3. Statistics about libraries are collected regularly and distributed promptly.

4. Research related to libraries and librarianship is available from ALA in response to requests.

5. Information and advisory services about libraries and librarianship are available from ALA in response to requests.

6. ALA encourages cooperative activities to improve service to library users.

7. ALA promotes access to information via technological means.

8. Librarians are able to use technology effectively.

9. Library funds are managed effectively.

10. Librarians practice effective public relations.

11. Libraries are proactive agencies which meet the challenges of social, economic, and environmental change.
II. A. To develop standards and guidelines.

IV.C. To advance the professional knowledge of academic librarians through an effective publishing program.

II.A.4. Promote the identification, collection and dissemination of academic library statistics.

IV.A. To identify research topics and to encourage improvement in research skills.

II.B. Publicize availability of Advisory Services.

IV.B. To support research projects, report works in progress and disseminate research results.

III.A.1. Create opportunities for academic librarians to interact with other professionals in the academic community.

\section{ALA Organizational Support Goals}

ACRL Strategic Management Directions

\section{Organizational Area A: ALA Roles and Relationships}

1. The activities and programs of ALA are coordinated.

2. ALA speaks with one voice for the profession.
6. Working collaboratively with other ALA units for the good of librarianship as a whole.

\section{Organizational Area B: ALA Finances}

1. ALA obtains a significant amount of income from sources other than dues.
2. Managing the financial resources of ACRL by relying on sound budgeting and accounting principles, including maintaining a reserve fund equal to at least $50 \%$ of the average annual expenditures over the three most recently completed years. 
2. ALA maintains adequate cash reserves.

3. New markets are developed for ALA's products and services.

4. ALA has a continuously updated, multiyear financial plan.

5. ALA provides accurate and timely financial reports to members, officers and staff.
2. Managing the financial resources of ACRL by relying on sound budgeting and accounting principles, including maintaining a reserve fund equal to at least $50 \%$ of the average annual expenditures over the three most recently completed years.

\section{Organizational Area C: Human Resources}

\section{ALA membership is large and stable.}

2. Large numbers of members are involved in the work of the association.

3. ALA leaders are effective.

4. ALA responds to the needs and interests of members.

5. ALA staff provides a high level of expertise and service. ities.

7. State library associations/chapters are fully informed about ALA activities.

8. Appropriate and timely data about the ALA membership is available.
4. Seeking new members through a variety of recruitment techniques, while extending efforts to retain present members, including regular assessments of member needs.

5. Supporting all elected and appointed officers in fulfilling their leadership roles through carefully prepared programs of orientation and staff personal attention.

3. Maintaining a dedicated and competent staff by depending on sound personnel practices, including careful selection, adequate training, participative management techniques, and opportunities for professional development.

\section{OCLC to exchange data with Germany}

OCLC, Inc., has signed an agreement with the Deutsches Bibliotheksinstitut (the German Library Institute) to explore ways in which both organizations may reduce effort and the unit cost of cataloging by sharing their respective databases. Both parties will seek to overcome technological barriers to such efforts by arranging for access to each other's data, software, research, and systems.

During the current phase of the accord, seven research libraries of the Federal Republic of Germany have been selected by the Deutsches Bibliotheksinstitut to participate in the evaluation of the OCLC database. The participants include the State Library of Prussian Culture, the University Library of the Free University of Berlin, the University Library of the Technical University of Berlin, the University Library of Dusseldorf, the University Library of Heidelberg, the University Library of Tübingen, and the University Library of Essen. Samples from each library's catalog will be searched in the OCLC database to determine if the bibliographic data found will be useful as a secondary source of data for the German library and information community.

A similar evaluation will be conducted by OCLC, in association with a number of its U.S. member libraries, accessing the serials and monographs union files maintained at the Deutsches Bibliotheksinstitut.

Two national databases, one for serials and the other for monographs, are managed by the Deutches Bibliotheksinstitut. The Zeitschriftendatenbank, produced in cooperation with the State Library of the Prussian Cultural Foundation, contains 430,000 serial titles representing over one million holdings of more than 1,000 libraries. The new monographic database contains about 4 million titles.

There are about 900,000 German-language titles in OCLC's database of 14 million records. 